\title{
First report of Cherry leaf roll virus (CLRV) in Malus domestica
}

\author{
E. N. Y. Woo • G. R. G. Clover • M. N. Pearson
}

Received: 23 May 2012 / Accepted: 30 August 2012 /Published online: 11 October 2012

(C) Australasian Plant Pathology Society Inc. 2012

\begin{abstract}
Cherry leaf roll virus (CLRV) was detected in apple (Malus sp.), a host not previously reported for CLRV in New Zealand. A total of 72 leaf samples were obtained from two orchards in the Waikato region of the North Island of New Zealand and tested by reverse transcriptionpolymerase chain reaction (RT-PCR). Virus-specific RTPCR, sequencing and mechanical inoculation on herbaceous host plants detected the presence of CLRV in three samples. This is the first report of CLRV on apple in New Zealand. Based on a thorough review of literature, results obtained in this study may likely represent the first case of CLRV in apple.
\end{abstract}

Keywords Cherry leaf roll virus · Malus sp. · RT-PCR . Phylogenetic analysis $\cdot$ Mechanical inoculation $\cdot$ New Zealand

Cherry leaf roll virus (CLRV) is a species within subgroup $\mathrm{C}$ of the Nepovirus genus, Secoviridae family (Sanfaçon et al. 2009). CLRV has a wide natural and experimental host range and causes economically significant diseases in horticultural crops. The virus was first described in 1955 causing a disease of sweet cherry in England (Posnette and Cropley

\section{E. N. Y. Woo $(\bowtie) \cdot$ M. N. Pearson}

School of Biological Sciences, The University of Auckland, Private Bag 92019,

Auckland 1142, New Zealand

e-mail: ewoo040@aucklanduni.ac.nz

G. R. G. Clover

Plant Health and Environment Laboratory,

New Zealand Ministry for Primary Industries,

PO Box 2095, Auckland 1140, New Zealand
1955). Subsequently the virus was reported to cause leaf rolling and plant death in cherry (Cropley 1961) and a range of other plant species including elderberry, olive, raspberry, rhubarb, walnut and a number of shrub, tree, weed and ornamental species (Ahmed and Bailiss 1975; Cooper and Atkinson 1975; Ford et al. 1972; Hansen and Stace-Smith 1971; Jones and Wood 1978; Larson et al. 1990; Mircetich and Rowhani 1984; Savino and Gallitelli 1981; Tomlinson and Walkey 1967; Walkey and Cooper 1973). The virus has been detected throughout Europe and North America (Bandte and Büttner 2001), Chile (Herrera and Madariaga 2001), Peru (Crosslin et al. 2010), New Zealand (Jones and Wood 1978; Veerakone et al. 2012), Japan (Yamashita and Fukui 2004), Australia and China (Jones 1985).

CLRV is naturally transmitted through seeds of woody perennial hosts which include birch, cherry, elderberry, elm, and walnut (Cooper et al. 1984; Massalski and Cooper 1984) or pollen (Card et al. 2007). It has also been experimentally graft-transmitted by bark patches of English walnut trees (Mircetich et al. 1980) and mechanically transmitted to a wide range of herbaceous species (Cropley 1961; Jones 1985). Unlike many other nepoviruses, CLRV appears not to be transmitted by soil-inhabiting nematodes (Jones et al. 1981; Wang et al. 2002) despite earlier reports to the contrary (Flegg 1969). More recently, it has been suggested that CLRV particles released from roots of infected Chenopodium quinoa plants are able to migrate through nutrient solution and infect healthy C. quinoa plants (Bandte et al. 2007).

During a recent survey of apple trees (Malus $\times$ domestica Borkh), predominantly the 'Royal Gala' variety on either Geneva 202 or MM106 rootstocks, some leaves were observed with leaf tip deformation, necrotic spots and mottling lesions (Fig. 1a \& b). A total of 72 leaf samples were tested for the presence of CLRV using a 1-tube reverse transcription- 
Fig. 1 Symptoms observed in apple leaves: a Leaf tip deformation; b Necrotic spots and mottling. Symptom development following inoculation of Cherry leaf roll virus in Nicotiana occidentalis: c Localized symptom of yellow mottling; d Systemic symptoms of lamina deformation, necrosis and yellow mottling

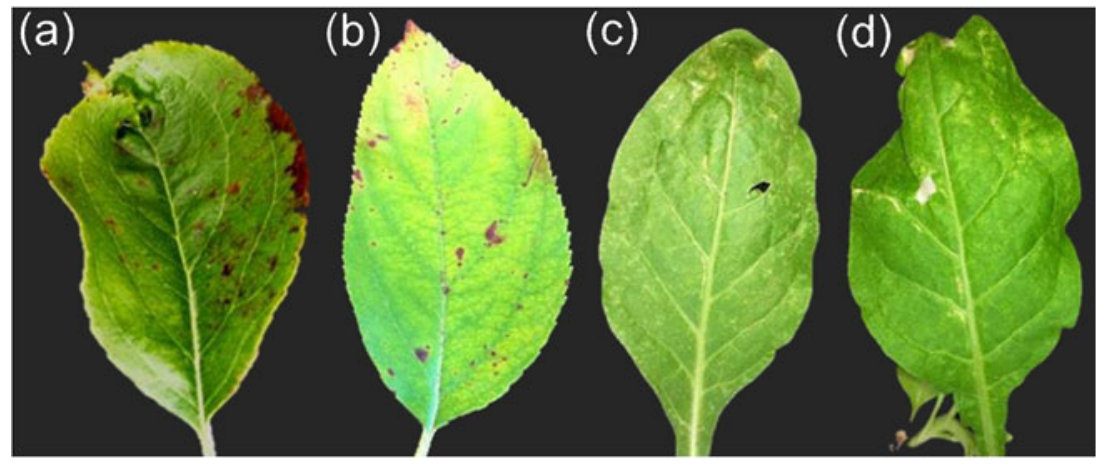

polymerase chain reaction (RT-PCR) protocol (Invitrogen, Carlsbad, CA, USA). Total RNA was extracted from leaf samples using the Qiagen RNeasy ${ }^{\circledR}$ Plant Mini Kit (Qiagen, Valencia, CA, USA) following the manufacturer's protocol. RT-PCR was done using the CLRV-specific primers of Werner et al. (1997). A PCR competency control using the nad5-s and nad5-as primers of Menzel et al. (2002) was included for all the RNA extracts tested. The cycling conditions were optimised during this study and consisted of 1 cycle of complementary DNA synthesis at $55^{\circ} \mathrm{C}$ for $30 \mathrm{~min}$, a single cycle of denaturation at $94{ }^{\circ} \mathrm{C}$ for $2 \mathrm{~min}$, followed by 40 cycles at $55{ }^{\circ} \mathrm{C}$ annealing for $30 \mathrm{~s}, 68{ }^{\circ} \mathrm{C}$ extension for $45 \mathrm{~s}$, and $94{ }^{\circ} \mathrm{C}$ denaturation for $15 \mathrm{~s}$, with a final extension at $68{ }^{\circ} \mathrm{C}$ for $5 \mathrm{~min}$.

RNA extracts from all the 72 leaf samples were confirmed to be RT-PCR competent using the nad5-s and nad5-as primers of Menzel et al. (2002) as a $180 \mathrm{bp}$ product was obtained from all the samples tested. Three samples produced amplicons of the expected size, these were cloned using a pGEM $^{\circledR}$ - $T$ easy vector systems kit (Promega Corporation, USA) and sequenced. The consensus sequences from four clones of two samples were deposited in the GenBank (Accession numbers JN581001, JN581002) while two clones from the third sample generated sequences that have a pairwise identity of only $96.8 \%$ to each other (Accession numbers JN581000, JQ822107). A BLASTn search of these amplicons in GenBank showed $96.8 \%-99.8 \%$ nucleotide identity to two New Zealand isolates from Rubus and Hydrangea (Accession numbers AJ877162, JN418885). The primer sequences described by Werner et al. (1997) were removed prior to performing a multiple sequence alignment with $58 \mathrm{CLRV}$ isolates selected from reports by Rebenstorf et al. (2006), von Bargen et al. (2011) and Veerakone et al. (2012) using the Geneious software (Drummond et al. 2011). Details of isolates obtained from the NCBI database are shown in Table 1. A Neighbour-Joining tree (Fig. 2) with bootstrap values of 1,000 replicates was constructed using Geneious (Drummond et al. 2011). The phylogenetic tree showed that one of the four CLRV sequences (Malus-JQ822107-New Zealand) clustered with phylogenetic group B according to Rebenstorf et al. (2006) while the other three (Malus-JN581000-New Zealand, MalusJN581001-New Zealand and Malus-JN581002-New Zealand) clustered with isolates of group C.

Sap from the three positive samples was used to inoculate three Nicotiana occidentalis plants. Localized and systemic symptoms of yellow mottling were observed 14 days post inoculation in all three plants (Fig. 1c \& d). The presence of CLRV in $N$. occidentalis was confirmed by direct sequencing amplicons with the expected size obtained by 1-tube RTPCR with CLRV-specific primers (Werner et al. 1997). A BLASTn search of these amplicons showed $92.4 \%$ $99.4 \%$ nucleotide identity to two New Zealand isolates from Rubus idaeus and Hydrangea macophylla (Accession numbers AJ877162, JN418885).

The finding of two sequences within a sample of leaves suggests the presence of two CLRV variants. While the clustering of the four CLRV Malus isolates in two phylogenetic groups suggests that it is not likely for the presence of an obvious specific host-virus association. This lack of a distinct phylogenetic grouping according to host has been reported previously (Bousalem et al. 2000; García-Arenal et al. 2001; Tomimura et al. 2004). The clustering in two phylogenetic groups also suggests that there may have been at least two separate introductions of CLRV into New Zealand. Additionally, Malus-JN581000-New Zealand, Malus-JN581001-New Zealand and Malus-JN581002-New Zealand also clustered together with sequences from two other New Zealand CLRV isolates (GenBank accession numbers AJ877162, JN418885) from red raspberry (Rubus idaeus) (Jones and Wood 1978) and Hydrangea macrophylla (Veerakone et al. 2012) respectively. Although the virulence of CLRV isolated from Malus in this study is still to be determined, CLRV isolated from red raspberry was reported to cause stunted growth with small and deformed leaves which had chlorotic mottling and ring spots (Jones and Wood 1978) and severe leaf deformation and chlorosis in Hydrangea macophylla (Veerakone et al. 2012). CLRV has also been reported to cause damaging diseases in cherry (Prunus avium) (Jones 1985) 


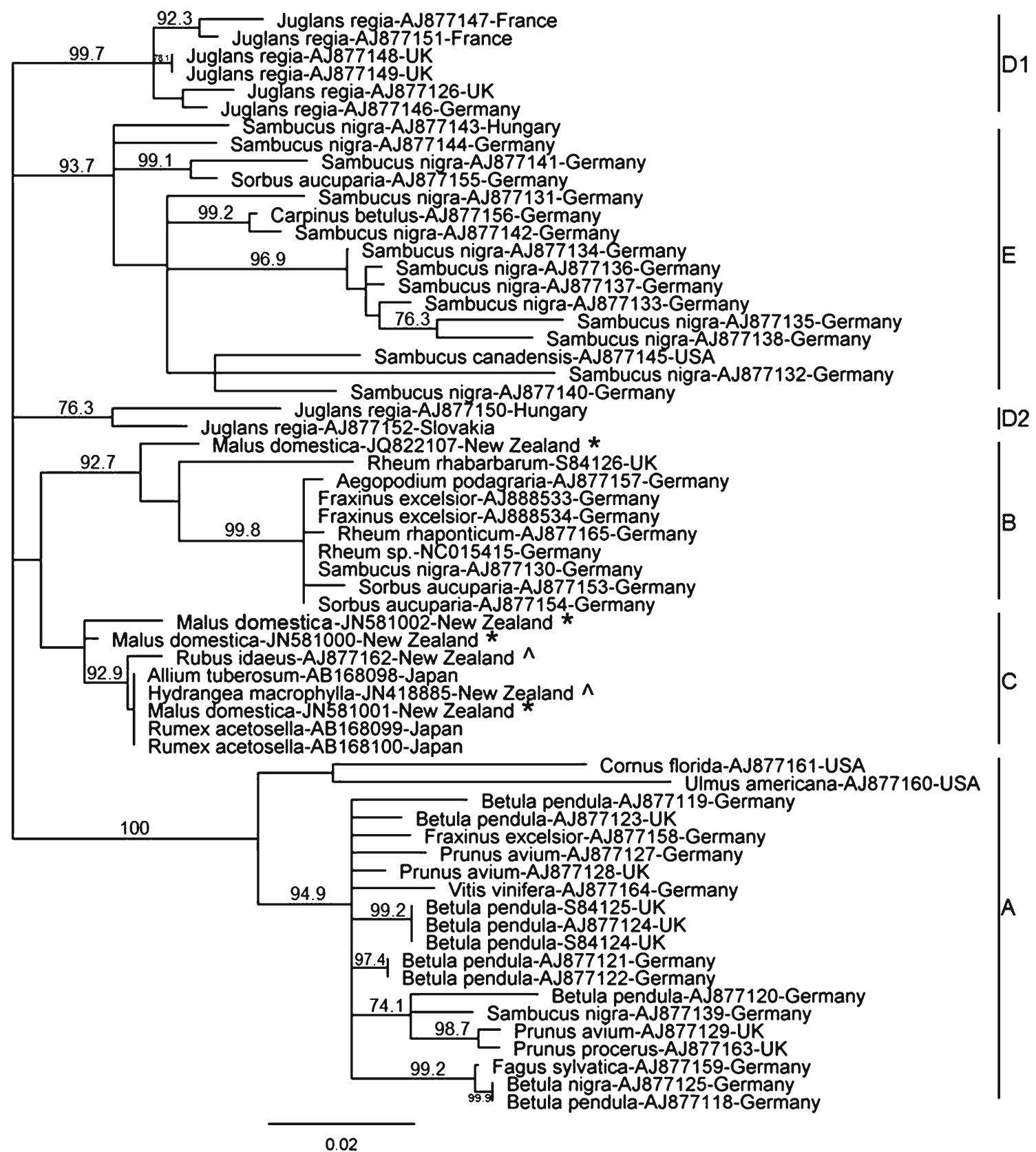

Fig. 2 Neighbour-Joining phylogenetic tree based on a 386 bp nucleotide sequence of the $3^{\prime}$ non-coding region of Cherry leaf roll virus isolates generated with Geneious (Drummond et al. 2011). The nodal significance was evaluated by 1,000 bootstrap replicates and probability estimate values larger than $70 \%$ are indicated at branch nodes.
CLRV isolates generated from this study are highlighted with * and the CLRV isolates already recorded as present in New Zealand are highlighted with ${ }^{\wedge}$. Phylogenetic groups, A to E, according to Rebenstorf et al. (2006) are indicated by bold lines on the right. Phylogenetic tree submitted to TreeBase (2012) and forest trees including beech (Fagus sylvatica) and birch (Betula sp.) (Werner et al. 1997). Hence, CLRV may have an economic impact on crops such as Malus and Prunus in New Zealand.

The virus isolated from Malus domestica Borkh was identified as CLRV based on molecular and phylogenetic analyses and mechanical inoculation of herbaceous test plants. It is understood that the finding of CLRV in apple is a new host record in New Zealand. A thorough review of literature did not reveal any report of an association between CLRV and apple. In view of this, results obtained in this study may likely represent the first case of CLRV in apple. 
Table 1 Cherry leaf roll virus isolates from the NCBI database included in the phylogenetic analyses

\begin{tabular}{|c|c|c|c|c|}
\hline Host plant & Accession no. & CLRV isolate & Geographic origin & Phylogenetic group ${ }^{\mathrm{a}}$ \\
\hline Aegopodium podagraria & AJ877157 & E575 & Fellinghausen, Germany & $\mathrm{B}$ \\
\hline Allium tuberosum & AB168098 & Chinese chive & Japan & $\mathrm{C}$ \\
\hline Betula nigra & AJ877125 & E836 & Hannover-Herrenhausen, Germany & A \\
\hline Betula pendula & AJ877118 & E120 & Berlin-Spandau, Germany & A \\
\hline Betula pendula & AJ877119 & E499 & Berlin-Zehlendorf-Berkaer Str., Germany & A \\
\hline Betula pendula & AJ877120 & E896 & Berlin-Zehlendorf-Thielallee, Germany & $\mathrm{A}$ \\
\hline Betula pendula & AJ877121 & E696 & Klövensteen, Germany & $\mathrm{A}$ \\
\hline Betula pendula & AJ877122 & E111 & Klövensteen, Germany & $\mathrm{A}$ \\
\hline Betula pendula & AJ877123 & E806 & UK & $\mathrm{A}$ \\
\hline Betula pendula & S84124 & $\mathrm{I}_{2}$-RNA-1 & UK & $\mathrm{A}$ \\
\hline Betula pendula & S84125 & $\mathrm{I}_{2}$-RNA-2 & UK & A \\
\hline Betula pendula & AJ877124 & E1469 & UK & A \\
\hline Carpinus betulus & AJ877156 & E141 & Niedereimer, Germany & $\mathrm{E}$ \\
\hline Cornus florida & AJ877161 & E797 & USA & A \\
\hline Fagus sylvatica & AJ877159 & E113 & Bonn-Siebengebirge, Germany & A \\
\hline Fraxinus excelsior & AJ877158 & E325 & Schwäbische Alb, Germany & $\mathrm{A}$ \\
\hline Fraxinus excelsior & AJ888533 & E678 & Andechs, Germany & $\mathrm{B}$ \\
\hline Fraxinus excelsior & AJ888534 & E698 & Idar-Oberstein, Germany & $\mathrm{B}$ \\
\hline Hydrangea macrophylla & JN418885 & - & New Zealand & $\mathrm{C}$ \\
\hline Juglans regia & AJ877146 & E326 & Bonn-Oberkassel, Germaany & D1 \\
\hline Juglans regia & AJ877147 & E648 & France & D1 \\
\hline Juglans regia & AJ877148 & 4WJUG & UK & D1 \\
\hline Juglans regia & AJ877149 & E800 & UK & D1 \\
\hline Juglans regia & AJ877126 & GAY & Gaydon, UK & D1 \\
\hline Juglans regia & AJ877150 & E156 & Trans-Danubia, Hungary & D2 \\
\hline Juglans regia & AJ877151 & CTIFL & France & D1 \\
\hline Juglans regia & AJ877152 & Ludmila & Slovakia & D2 \\
\hline Malus domestica & JN581000 & 26AYLS & This study & $\mathrm{C}$ \\
\hline Malus domestica & JQ822107 & 26BYLS & This study & $\mathrm{B}$ \\
\hline Malus domestica & JN581001 & $54 \mathrm{OHS}$ & This study & $\mathrm{C}$ \\
\hline Malus domestica & JN581002 & 66OHS & This study & $\mathrm{C}$ \\
\hline Prunus avium & AJ877127 & E327 & Bonn, Germany & $\mathrm{A}$ \\
\hline Prunus avium & AJ877128 & E803 & UK & A \\
\hline Prunus avium & AJ877129 & E1472 & UK & $\mathrm{A}$ \\
\hline Rheum rhaponticum & AJ877165 & E395 & Bornheim, Germany & $\mathrm{B}$ \\
\hline Rheum rhabarbarum & S84126 & R25-RNA-1 & UK & $\mathrm{B}$ \\
\hline Rheum sp. & NC015415 & E395 & Bornheim, Germany & $\mathrm{B}$ \\
\hline Rumex acetosella & AB168099 & Rumex AGBC & Japan & $\mathrm{C}$ \\
\hline Rumex acetosella & AB168100 & Rumex acetosella-21 & Japan & $\mathrm{C}$ \\
\hline Rubus idaeus & AJ877162 & E802 & New Zealand & $\mathrm{C}$ \\
\hline Rubus procerus & AJ877163 & E805 & UK & A \\
\hline Sambucus canadensis & AJ877145 & E804 & USA & $\mathrm{E}$ \\
\hline Sambucus nigra & AJ877130 & E676 & Helgoland, Germany & $\mathrm{B}$ \\
\hline Sambucus nigra & AJ877131 & E485 & Fischland, Germany & $\mathrm{E}$ \\
\hline Sambucus nigra & AJ877132 & E603 & Werder, Germany & $\mathrm{E}$ \\
\hline Sambucus nigra & AJ877133 & E583 & Neuruppin, Germany & $\mathrm{E}$ \\
\hline Sambucus nigra & AJ877134 & E119 & Berlin-Zehlendorf-Lentzeallee I, Germany & $\mathrm{E}$ \\
\hline Sambucus nigra & AJ877135 & E622 & Berlin-Zehlendorf-Lentzeallee II, Germany & $\mathrm{E}$ \\
\hline Sambucus nigra & AJ877136 & E839 & Berlin-Zehlendorf-Lentzeallee III & $\mathrm{E}$ \\
\hline
\end{tabular}


Table 1 (continued)

\begin{tabular}{lllll}
\hline Host plant & Accession no. & CLRV isolate & Geographic origin & Phylogenetic group $^{\text {a }}$ \\
\hline Sambucus nigra & AJ877137 & E541 & Berlin-Zehlendorf-Bitterstr. & E \\
Sambucus nigra & AJ877138 & E443 & Berlin-Neuköllin & E \\
Sambucus nigra & AJ877139 & E441 & Aschersleben & A \\
Sambucus nigra & AJ877140 & E950 & Aschersleben & E \\
Sambucus nigra & AJ877141 & E568 & Balve & E \\
Sambucus nigra & AJ877142 & E576 & Fellinghausen & E \\
Sambucus nigra & AJ877143 & E492 & Sümeg & E \\
Sambucus nigra & AJ877144 & PV-0276 & Bonn-Siebengebirge & E \\
Sorbus aucuparia & AJ877153 & E697 & Hamburg-Osdorfer Born & B \\
Sorbus aucuparia & AJ877154 & E695 & Titisee-Neustadt, Germany & B \\
Sorbus aucuparia & AJ877155 & E693 & USA & E \\
Ulmus americana & AJ877160 & E801 & Neustadt-W.-Königsbach, Germany & A \\
Vitis vinifera & AJ877164 & E1636 & A \\
\hline
\end{tabular}

${ }^{\text {a }}$ Phylogenetic grouping according to Rebenstorf et al. (2006)

Acknowledgements The first author would like to thank Sunfruit Orchards, Hamilton, New Zealand for allowing samples to be obtained from their orchards and Karina Ho and Shamini Pushparajah for sample collection. This study was supported by a research grant to the first author from the New Zealand Ministry for Primary Industries.

\section{References}

Ahmed AH, Bailiss KW (1975) Virus infection of Delphinium in Britain. J Hortic Sci 50:47-54

Bandte M, Büttner C (2001) A review of an important virus of deciduous trees - Cherry leaf roll virus: occurrence, transmission and diagnosis. Pflanzenschutzberichte 59:1-19

Bandte M, Eschevarria-Laza HJ, Paschek U, Ulrichs C, Pestemer W, Schwarz D and Büttner C (2007) Transmission of plant viruses by water. In: Fischer G, Magnitskiy S, Flórez LE, Miranda D and Medina A (eds.). Sociedas Columbiana de Ciencias Horticolas. In: Proceedings of the $2^{\text {nd }}$ Columbian Congress for Horticulture, Bogota, Columbia, 12-14 Sept., pp. 31-43

Bousalem M, Douzery E, Fargette D (2000) High genetic diversity, distant phylogenetic relationships and intraspecies recombination events among natural populations of Yam mosaic virus: a contribution to understanding potyvirus evolution. J Gen Virol 81:243255

Card SD, Pearson MN, Clover GRG (2007) Plant pathogens transmitted by pollen. Australas Plant Pathol 36:455-461

Cooper JI, Atkinson MA (1975) Cherry leaf roll virus causing a disease of Betula spp. in the United Kingdom. Forestry 48:193203

Cooper JI, Massalski PR, Edwards ML (1984) Cherry leaf roll virus in the female gametophyte and seed of birch and its relevance to vertical transmission. Ann Appl Biol 105:55-64

Cropley R (1961) Cherry leaf-roll virus. Ann Appl Biol 49:524-529

Crosslin JM, Eastwell KC, Davitt CM, Abad JA (2010) First report of seedborne Cherry leaf roll virus in wild potato, Solanum acaule, from South America. Plant Dis 94:782

Drummond AJ, Ashton B, Buxton S, Cheung M, Cooper A, Duran C, Field M, Heled J, Kearse M, Markowitz S, Moir R, Stones-Havas S, Sturrock S, Thierer T, Wilson A (2011) Geneious v5.4. http:// www.geneious.com
Flegg JJM (1969) Tests with potential nematode vectors of cherry leaf roll virus. In: Report of East Malling Research Station for 1968, 115

Ford RE, Moline HE, McDaniel GL, Mayhew DE, Epstein AH (1972) Discovery and characterization of Elm mosaic virus in Iowa. Phytopathology 62:987-992

García-Arenal F, Fraile A, Malpica J (2001) Variability and genetic structure of plant virus populations. Annu Rev Phytopathol 39:157-186

Hansen AJ, Stace-Smith R (1971) Properties of a virus isolated from golden elderberry, Sambucus nigra aurea. Phytopathology 61:1222-1229

Herrera G, Madariaga M (2001) Presence and incidence of grapevine viruses in the central zone of Chile. Agricultura Tecnica 61:393-400

Jones AT (1985) Cherry leaf roll virus. CMI/AAB Descriptions of plant viruses, No. 306, 9 pp

Jones AT, Wood GA (1978) The occurrence of cherry leaf roll virus in red raspberry in New Zealand. Plant Dis Rep 62:835-838

Jones AT, McElroy FD, Brown DJF (1981) Tests for transmission of cherry leaf roll virus using Longidorus, Paralongidorus and Xiphinema nematodes. Ann Appl Biol 99:143-150

Larson RC, Gergerich RC, Kim KS (1990) Characterization and ultrastructural studies of a nepovirus from Euonymus. Phytopathology 80:134-140

Massalski PR, Cooper JI (1984) The location of virus-like particles in the male gametophyte of birch, walnut, cherry naturally infected with CLRV and its relevance to vertical transmission of the virus. Plant Pathol 33:255-262

Menzel W, Jelkmann W, Maiss E (2002) Detection of four apple viruses by multiplex RT-PCR assays with coamplification of plant mRNA as internal control. J Virol Methods 99:81-92

Mircetich SM, Rowhani A (1984) The relationship of cherry leafroll virus and blackline disease of English walnut trees. Phytopathology $74: 423-428$

Mircetich SM, Sanborn RR, Ramos DE (1980) Natural spread, grafttransmission, and possible etiology of walnut blackline disease. Phytopathology 70:962-968

Posnette AF and Cropley R (1955) Leafroll: a virus disease of cherry. In: Report of East Malling Research Station for 1954, 126-127

Rebenstorf K, Candresse T, Dulucq MJ, Buttner C, Obermeier C (2006) Host species-dependent population structure of a pollenborne plant virus, cherry leaf roll virus. J Virol 80:2453-2462 
Sanfaçon H, Wellink J, Le Gall O, Karasev A, van der Vlugt R, Wetzel $\mathrm{T}$ (2009) Secoviridae: a proposed family of plant viruses within the order Picornavirales that combines the families Sequiviridae and Comoviridae, the unassigned genera Cheravirus and Sadwavirus, and the proposed genus Torradovirus. Arch Virol 154:899907

Savino V, Gallitelli D (1981) Cherry leaf roll virus in olive. Phytopathologia Mediterranea 20:202-203

Tomimura K, Špak J, Katis N, Jenner CE, Walsh JA, Gibbs AJ, Ohshima K (2004) Comparisons of the genetic structure of populations of Turnip mosaic virus in West and East Eurasia. Virology 330:408-423

Tomlinson JA, Walkey DGA (1967) The isolation and identification of rhubarb viruses occurring in Britain. Ann Appl Biol 59:415-427

TreeBase (2012) http://purl.org/phylo/treebase/phylows/study/TB2: S12728
Veerakone S, Liefting LW, Lebas BSM, Ward L (2012) First report of Cherry leaf roll virus in Hydrangea macrophylla. Plant Dis 96:463

von Bargen S, Langer J, Robel J, Rumbou A and Büttner C (2011) Cherry leaf roll virus RNA2, complete genome. NCBI Reference Sequence: NC 015415.1

Walkey DGA, Cooper VC (1973) Report of the National Vegetable Research Station for 1972., pp 100-102

Wang S, Gergerich RC, Wickizer SL, Kim KS (2002) Localization of transmissible and nontransmissible viruses in the vector nematode Xiphinema americanum. Phytopathology 92:646-653

Werner R, Mühlbach H-P, Büttner C (1997) Detection of cherry leaf roll nepovirus (CLRV) in birch, beech and petunia by immunocapture RT-PCR using a conserved primer pair. Eur J For Pathol 27:309-318

Yamashita K and Fukui Y (2004) Cherry leaf roll virus RNA1, 3' end. Direct submission to GenBank 